This is an Accepted Manuscript of an article published by Cambridge University Press, Language in Society, available at https://www.cambridge.org/core/journals/language-insociety/article/mother-tongues-and-languaging-in-malaysia-critical-linguistics-under-criticalexamination/63E9315695008B98517AA546BF6C5F54

\title{
Mother tongues and languaging in Malaysia: Critical linguistics under critical examination
}

\author{
Nathan John Albury
}

\begin{abstract}
This article brings the critical turn in linguistics - with its current scepticism of essentialised languages and bias for languaging - under critical evaluation. It does so by bringing it faceto-face with the local-knowledge turn in sociolinguistics that emphasises local knowledge, held by language users themselves, to understand sociolinguistic phenomena through local epistemologies. This paper analyses whether and how epistemologies inherent to language, mother tongue and languaging hold relevance in metalinguistic talk in Malaysia. Focus group discussions with ethnic Malay, Chinese and Indian youth revealed that languaging through Bahasa Rojak is already firmly embedded in local epistemology for communicating across ethnolinguistic divides and fostering interethnic inclusiveness. However, an essentialised view of language also remains vital to any holistic sociolinguistic research in Malaysia in culturally-specific ways that do not conflict with languaging. The paper especially supports arguments that we ought not to disregard mother tongues in the interests of critical linguistics.
\end{abstract}

\section{Key words}

Critical linguistics, Mother tongue, Languaging, Linguistic culture, Malaysia, Folk linguistics 
This is an Accepted Manuscript of an article published by Cambridge University Press,

Language in Society, available at https://www.cambridge.org/core/journals/language-insociety/article/mother-tongues-and-languaging-in-malaysia-critical-linguistics-under-criticalexamination/63E9315695008B98517AA546BF6C5F54

\section{Introduction}

Sociolinguistics has evolved to an era where the term mother tongue can raise eyebrows. As scholarship increasingly applies a critical lens to investigate how languages are used in society, it has edged further away from analysing languages in essentialised forms to instead analyse language (Jørgensen 2008). We recognise that the notion that discreet languages and mother tongues exist is an essentialist and modernist construct, steeped in a supposed correlation between language to ethnicity (Blommaert, Leppänen \& Spotti 2012) and the normativity of monolingualism in the language of an imagined community (Pennycook 2002). A more accurate picture, it has been argued since the pioneering anthropological works of Gumperz and Hymes (1972) and Silverstein's (1996) discussion of speech communities versus language communities, is that language is a communicative resource held by individuals. Because language is a social phenomenon, language behaviours tend not to comply with the ideological notion of mother tongues and are instead more creative, boundless, and complex.

This is especially the case in linguistically diverse societies homes to people traditionally seen as multilingual. Multilinguals are no longer considered the embodiment of many monolinguals who switch between languages, but are instead seen as possessing complex linguistic repertoires. Language is therefore a resource, and communication may be characterised by meaning-making and 'linguistic practices that exploit a multilingual mix and syncretism of form and function' (Stroud 2003). This thinking has inspired recent terms such as languaging (Jørgensen 2008), translanguaging (Wei 2011), metrolingualism (Otsuji \& Pennycook 2010) polylingualism (Møller \& Jørgensen 2009) and networked multilingualism (Androutsopoulos 2015) (from here on referred to collectively as languaging in the interests 
This is an Accepted Manuscript of an article published by Cambridge University Press,

Language in Society, available at https://www.cambridge.org/core/journals/language-insociety/article/mother-tongues-and-languaging-in-malaysia-critical-linguistics-under-criticalexamination/63E9315695008B98517AA546BF6C5F54

of brevity). These scholars agree that language behaviours are not bound to rigid ideological constructs of mother tongue and languages, but are dynamic, fluid and laced with discursive identity constructions and meaning-making to achieve communicative goals. This liberates multilinguals and their complex repertoires from essentialist views of language that may otherwise marginalise their nonconforming practices.

This paper, however, places these products of critical linguistics under a critical lens. Critical linguistics takes lead from postmodernism and its aversion for grand narratives, meaning critical analysis can never come to a final truth. Therefore we should never be 'ideologically committed to a single perspective' (Widdowson 2001:15). In as far as critical linguistics problematises the notions of languages and mother tongue, the spirit of critical theory also argues that 'this problematizing stance must also be turned on itself' (Pennycook 2004:800). This paper does this by leveraging off Pennycook's (2002) mention that despite our recent theorising, we need to work 'contextually' because 'the notion of the mother tongue' might nonetheless be 'shared across communities but related in different ways to different contexts' (p. 23). It brings our general scepticism of mother tongues and preference for languaging when examining language behaviour face-to-face with the local-knowledge turn that is currently underway in sociolinguistics to examine local knowledge amongst language users. This emphasises linguistic cultural context (1995b; Schiffman 2006), as well as local epistemology, knowledge and narratives about sociolinguistic phenomena (see for example Canagarajah 2005b; Preston 2005; Preston 2011; Albury 2016b; Albury 2016a). For this paper, this means investigating to what extent essentialised views of mother tongue, and the postmodern ideas inherent to languaging, hold clout in local linguistic cultures and epistemologies of language. 
This is an Accepted Manuscript of an article published by Cambridge University Press,

Language in Society, available at https://www.cambridge.org/core/journals/language-insociety/article/mother-tongues-and-languaging-in-malaysia-critical-linguistics-under-criticalexamination/63E9315695008B98517AA546BF6C5F54

This paper addresses that question in the case of multilingual Malaysia. By applying a folk linguistic approach (Preston 2005; Preston 2011), the paper analyses the metalinguistic talk of a cohort of Malay, Chinese and Indian youth in peninsula Malaysia, retrieved through a series of 24 focus group discussions, about the nature of language, and societal and individual multilingualism, in Malaysian society. It argues that while the widespread practice of languaging across ethnolinguistic divides, known as Bahasa Rojak, holds a prominent place for these youth in understanding their own sociolinguistic realities, the terms languages and mother tongue are also indispensable to local linguistic epistemology. The students draw on - and need - an essentialised view of languages to explain Manglish as a result of contact between two languages, and to assert the local culturally-specific pertinence of mother tongues. There, mother tongues are commonly viewed as a language spoken by an ethnic collective, regardless of individual language proficiency, to locate speakers in contemporary Malaysia. It is argued that because the term mother tongue structures local sociolinguistic realities, and is 'contextually produced' (Pennycook 2002:23), it should remain at the forefront of holistic studies in Malaysian sociolinguistics, and indeed perhaps more broadly, parallel to languaging that may be observed in practice. What is more, by examining folk linguistic discourses vis-à-vis local cultural and historical context, mother tongues and languaging need not be seen as epistemologically exclusive, but may be complementary.

\section{Language beyond languages and mother tongue}

Pennycook and Makoni (2005) argue that the notion of languages is a social invention of the Christian colonial project, rooted in an 'ideology of languages as separate and enumerable categories' (p. 138). The essentialised view that discreet individual languages exist - 
This is an Accepted Manuscript of an article published by Cambridge University Press,

Language in Society, available at https://www.cambridge.org/core/journals/language-insociety/article/mother-tongues-and-languaging-in-malaysia-critical-linguistics-under-criticalexamination/63E9315695008B98517AA546BF6C5F54

including mother tongues - attained legitimacy through European invention as colonialists counted, and labelled the languages they encountered, thereby calling them 'into being' ( $p$. 143). The impact has been strong in academia too, with linguistics relying on an essentialised view of language in terms such as mother tongue education, multilingualism, language planning, language acquisition, and code-switching (Makoni \& Pennycook 2005, 2012; Møller \& Jørgensen 2009). Recognising that languages are socially-constructed, Pennycook and Makoni (2005) argue to 'disinvent and reconstitute languages, a process that may involve becoming aware of the history of invention, and rethinking the ways we look at languages and their relation to identity, geographical location and other social practices' (p. 138).

In doing that disinvesting, critical scholarship has seen the rise of numerous postmodern terms to analyse linguistic behaviour that is more creative and boundless than an essentialised view of language can accommodate. Androutsopoulos (2015) provides a useful overview of these nonessentialised terms. Polylingual languaging, for example, argues that 'the specific linguistic feature, and not the specific language, better characterises a given production’ (Jørgensen 2008:165). Androutsopoulos' (2015) own notion of networked multilingualism concerns 'multilingual practices that are shaped by two interrelated processes: being networked, i.e. digitally connected to other individuals and groups, and being in the network, i.e. embedded in the global digital mediascape of the web' (p. 188) with an emphasis on exploiting linguistic opportunities within digital technology. Translanguaging is 'an approach to bilingualism that is centred, not on languages as has often been the case, but on the practices of bilinguals that are readily observable in order to make sense of their multilingual worlds' (García 2009:140). Metrolingualism focuses on the 
This is an Accepted Manuscript of an article published by Cambridge University Press,

Language in Society, available at https://www.cambridge.org/core/journals/language-insociety/article/mother-tongues-and-languaging-in-malaysia-critical-linguistics-under-criticalexamination/63E9315695008B98517AA546BF6C5F54

city and 'describes the ways in which people of different and mixed backgrounds use, play with and negotiate identities through language' (Otsuji \& Pennycook 2010:246). Importantly, Otsuji and Pennycook add that metrolingualism

does not assume connections between language, culture, ethnicity, nationality or geography, but rather seeks to explore how such relations are produced, resisted, defied or rearranged; its focus is not on language systems but on languages as emergent from contexts of interaction activity can be better describe (ibid, p. 246).

All are united by the premise that 'language users employ whatever linguistic features are at their disposal to achieve their communicative aims’ (Ag \& Jørgensen 2013:528), make meaning in ways that are 'intentional and creative' (Fowler \& Hodges 2011:147), and do not adhere to essentialised definitions of language.

Languaging therefore calls into question the relevance of mother tongues, with the view that these too are ideological constructs embedded in social and political histories. The idea of the mother tongue is a cornerstone of modern socio-political citizenship (Pennycook 2002; Wright 2003). It connects speakers and indexes the identity of a defined collective. However, mother tongue discourses are intrinsically connected to the monolingual ideology, which Ag and Jørgensen (2013) define as the belief that every person must have a particularly 'close relationship to one language' (p. 527). This disregards the often complex language repertoires and practices that individuals develop from childhood, especially where relationships are formed with various codes and movement between languages is common. Similarly, the notion of mother tongue conflicts with the language profiles of multilinguals who do not hold native-like competence in any one of their languages, given they employ their languages for different purposes in different domains. Accordingly, scholarship on language practice has moved beyond seeing such individuals as semilinguals (Hansegård 
This is an Accepted Manuscript of an article published by Cambridge University Press,

Language in Society, available at https://www.cambridge.org/core/journals/language-insociety/article/mother-tongues-and-languaging-in-malaysia-critical-linguistics-under-criticalexamination/63E9315695008B98517AA546BF6C5F54

1968), instead preferring to view individuals as possessing single or truncated linguistic repertoires (Blommaert 2010) and to examine language behaviours as they cross the boundaries of essentialised languages.

While this critical perspective on language originates in work on language behaviour, its influence in sociolinguistics is growing, especially in education. Literacy studies argue for the incorporation of, and support for, heteroglossic, non-standard bilingualism and biliteracies as public policy in classrooms (Flores \& Schissel 2014), to accept interlanguage repertoires (Long 1987) and to 'go beyond tests and surveys to document and interpret the social meaning of success and failure of bilingual education' (Hymes 1980:117). Pennycook (2002) warns us, however, not to do away entirely with the terms language and mother tongues because 'the notions of the mother tongue and mother-tongue education are often held up as political icons like democracy, universal education, or gender equality' (p. 11), and Jørgensen (2008) too acknowledges that languages and mother tongues can hold ideological relevance because 'some speakers think their languages should be kept apart' ( $\mathrm{p}$. 161). For example, essentialising languages may be needed, including by multilinguals, as political fodder to call for and implement language rights with the identity and cultural connotations attached to mother tongue, to plan the acquisition of second languages, to offer language services to migrants, and to manage international communication. However as academics, Pennycook (2002) argues, we need to understand the mother tongue as 'strategically essentialist' (p. 24), and therefore use it with caution and scepticism when applying it more broadly.

My concern is whether these critical positions developed in the global North on languages and mother tongue through analyses of language behaviour are still too loaded 
This is an Accepted Manuscript of an article published by Cambridge University Press,

Language in Society, available at https://www.cambridge.org/core/journals/language-insociety/article/mother-tongues-and-languaging-in-malaysia-critical-linguistics-under-criticalexamination/63E9315695008B98517AA546BF6C5F54

with western biases. Pondering this is to be reflexively critical of our stance on mother tongues and languaging. Critical thinking invites us, after all, 'to question the received categories of linguistics and applied linguistics. Such a questioning must include even those most basic concepts such as language and mother tongue' (Pennycook 2002:25). Added to this, we are experiencing a local-knowledge turn in sociolinguistics. This builds on the tradition of linguistic anthropology and interactional sociolinguistics that examines local linguistic behaviours dating back to Hymes (cf. 1972, 1974) and Gumperz (cf. 1964). The local-knowledge turn, however, increasingly engages the epistemologies, knowledge, and experiences of language users themselves to inform sociolinguistic research through local metalinguistic talk (Canagarajah 2005b; Preston 2005; Ryon 2005; Schiffman 2006; Albury 2016b), complementary to analyses by linguists of language behaviour. For example, it is useful to recall work carried out in neighbouring Indonesia on lay perspectives of language contact. There, Goebel (2014) observed that Indonesian speakers apply metalinguistic knowledge to code-switch strategically into Javanese to create specific interactional stances, and that Indonesians use and perceive lexical borrowings to enregister ethnic affiliations (ibid 2012). Errington's (1998) work on language contact found locals defining Bahasa GadohGadoh as lexical borrowing from Indonesian into Javanese, albeit the language contact is more complex, and that speakers showed little ability to explain how and why they shift from polite to informal registers when thinking out loud.

The notion is that scholarship can benefit from 'an ongoing conversation with local knowledge - if not to respect the aspirations and wholeness of marginalized communities, then at least for our common academic pursuit of broadening knowledge construction practices' (Canagarajah 2005b:20). In essence, this local-knowledge turn argues that valid 
This is an Accepted Manuscript of an article published by Cambridge University Press,

Language in Society, available at https://www.cambridge.org/core/journals/language-insociety/article/mother-tongues-and-languaging-in-malaysia-critical-linguistics-under-criticalexamination/63E9315695008B98517AA546BF6C5F54

knowledge that explains local sociolinguistic phenomena might be found outside academia within local communities. Similarly, folk linguistics researches what non-academicians claim to know, or indeed do not know, about linguistic phenomena. It reminds us that 'folk belief reflects dynamic processes which allow non-specialists to provide an account of their worlds' (Preston 1994:285) and that local knowledge 'can play an equal or greater role in the formation of discourses about language in society' (Albury 2016a:292). This all suggests that before we herald languaging as the optimal way forward, we ought to place the products of our critical thinking under critical examination by investigating whether and how the ideas inherent to these terms do, or do not, hold currency amongst language users themselves.

\section{Languages, mother tongues and languaging in Malaysia}

Malaysia is a valuable case study as a highly multilingual society in the global South which has not produced the critical scholarship discussed above. Malaysia has long served as a nonwestern crossroads of ethnicities, cultures, religions and languages in Southeast Asia. Waves of migration especially from southern China and India from the $14^{\text {th }}$ century and peaking in the late 1800s, plus Indigenous ethnic diversity across the peninsula and Borneo, means ethnic Malays have long shared their homeland with others (Hashim 2009). The Bumiputera - 'sons of the soil' comprising Malays and non-Malays indigenous to the Malaysian peninsula and Malaysian Borneo - form $67.4 \%$ of the population, the Chinese form $24.6 \%$, and the Indians constitute 7.3\% (Department of Statistics Malaysia 2010).

The traditional language (admitting the term is essentialised here) of the Malay is Bahasa Melayu, who commonly link their ethnicity and language to being Muslim (Frith 2000). The advent of trade with the West and the Middle East, plus the country's location as 
This is an Accepted Manuscript of an article published by Cambridge University Press,

Language in Society, available at https://www.cambridge.org/core/journals/language-insociety/article/mother-tongues-and-languaging-in-malaysia-critical-linguistics-under-criticalexamination/63E9315695008B98517AA546BF6C5F54

a maritime crossroads, allowed Bahasa Melayu to serve as the lingua franca of regional business. Today, Indonesia, Brunei and Singapore also share Bahasa Melayu as an official language. In Malaysia, Bahasa Melayu is characterised by dialect clusters that host internal variation (Omar, Jaafar \& Mat 2015). The Kelantan and Terengganu dialect clusters, both housed by the most conservative Islamic states of Malaysia, are seen as especially unique in their phonological features and vocabulary and are oftentimes problematic for speakers from other clusters (Omar, Jaafar \& Mat 2015). As Don (2003) explains, the dialect is 'a fundamental part of their regional culture and a symbol of group membership and loyalty' and speakers 'refer to the non-Kelantanese as oghei luwa ('outside people')' (p. 23). Importantly, that membership and loyalty is connected to a shift to conservative local interpretations of Islamic politics (Stark 2004).

Non-Malays have typically retained their languages. The Chinese use various languages, such as Hokkien (for example in Penang and the northern peninsula), Cantonese (Kuala Lumpur and surrounds), Hakka and Foochow (Sabah and Sarawak on Borneo), and others including Hakka, Teochew, and Hainanese. Tamil is the predominant heritage language of the Indian community, however some use Malayalam, Telugu, Punjabi and Hindi (Gill 2013), and a shift to English is also common (Schiffman 1995a; David, Naji \& Kaur 2003). Mostly in Sarawak and Sabah, the largely Christian and non-Malay Indigenous majority uses various languages, including Bidayuh, Iban, and Dusun-Kadazan, but are experiencing shift to Bahasa Melayu (Coluzzi, Riget \& Xiaomei 2013). Additionally, English had served as a lingua franca between ethnic groups - including the Malay - under British colonial rule, and is still commonly used in interethnic communication (Jenkins, Cogo \& Dewey 2011). 
This is an Accepted Manuscript of an article published by Cambridge University Press,

Language in Society, available at https://www.cambridge.org/core/journals/language-insociety/article/mother-tongues-and-languaging-in-malaysia-critical-linguistics-under-criticalexamination/63E9315695008B98517AA546BF6C5F54

For the Malaysian government, building a contemporary postcolonial society meant defining the nation, by law, as culturally Malay. Islam was established as the national religion, and Bumiputera became entitled to socioeconomic benefits not available to others, such as tax breaks and employment quotas, to rectify their socioeconomic disadvantage relative to the Chinese and Indians. This was also achieved through language policy, whereby Bahasa Melayu was codified as the single official language and positioned as the language of all Malaysian citizens, suppressing the value of English language proficiency which advantaged the non-Malays (Albury \& Aye 2016; Noor \& Leong 2013). A critical perspective also notes that Malay discourses construct Chinese- and Indian-Malaysians as pendatang, or 'visitors', thereby denying their Malaysian citizenship of cultural and linguistic authenticity. Language rights for non-Malays are restricted to primary-level minoritymedium education, however Chinese schools are exclusively Mandarin-medium, reflecting the status of Mandarin as the Chinese community's lingua franca, and Indian-medium education is currently only available in Tamil (Gill 2013). The government funds no secondary-level education other than through Bahasa Melayu, and admission to public universities requires graduation from a Malay-medium high school. Demands from the Chinese and Indian communities for a merit-based society led to a series of protests and policy programmes such as Bangsa Malaysia that urged Malaysians to identify on the basis of citizenship than on ethnicity (Ridge 2004) and 1Malaysia that promotes equality and meritocracy. Amidst this discourse, Bahasa Melayu was renamed Bahasa Malaysia to connote its role as a marker of Malaysian unity. Nonetheless, the Malays retain extra socioeconomic rights, and perhaps because of this history of race relations, essentialised 
This is an Accepted Manuscript of an article published by Cambridge University Press,

Language in Society, available at https://www.cambridge.org/core/journals/language-insociety/article/mother-tongues-and-languaging-in-malaysia-critical-linguistics-under-criticalexamination/63E9315695008B98517AA546BF6C5F54

ethnic identities remain the single most defining element of contemporary Malaysian society (Frith 2000; Hamayotsu 2014).

Language contact amidst this linguistic diversity has rendered language mixing common in Malaysia, inspiring a suite of sociolinguistic research on code-switching (see for example David 2003; Don 2003; Lau \& Ting 2013). While there is diversity in sociolinguistic theory on defining code-switching (cf. Auer 1988; Milroy \& Muysken 1995), studies on code-switching in Malaysia tend to adhere to an essentialised view of language concerning 'language choice and who uses what language to whom in the mixed discourse used by Malaysians' (David 2003:10) by specifically quantifying switches between discreet languages with a focus on system and form (Lau \& Ting 2013). In particular, Manglish is used to define code-switching between Bahasa Malaysia and English as discreet languages, especially at the intra-sentential level. This was exemplified in Shafie and Nayan's (2013) research of Facebook posts where Malay university students used Manglish, usually with a Malay substrate. For example (English in bold):

bdway thank you for choc bole mkn bila stress nanti

(by the way thank you for chocolate. I can eat it when I am stress later)

nkm suk tidoq gakni. Haha Good Luck noh final next week nih :) Nk off dah..byebye (I am going to bed. Good luck with your final next week. I will be offline. Bye bye.) (p. 194)

Manglish might be seen as falling under the umbrella term Bahasa Rojak (salad language). As a result of languages in contact to which Malaysians are accustomed, Saraceni (2013) describes Bahasa Rojak as hybridity that is so normative it has 'become a culture' (p. 200). He explains, for example, that that Tamil word macha (buddy) is used by all ethnic groups, regardless of the substrate language at play. However, unlike Manglish, Bahasa 
This is an Accepted Manuscript of an article published by Cambridge University Press,

Language in Society, available at https://www.cambridge.org/core/journals/language-insociety/article/mother-tongues-and-languaging-in-malaysia-critical-linguistics-under-criticalexamination/63E9315695008B98517AA546BF6C5F54

Rojak can include talk that employs more than two languages, at both the inter- and intrasentential level (McLellan 2012; Nil \& Paramasivam 2012). For example, in the following sequence adapted from David et al (2009:14), an Indian-Malaysian family discusses exercise:

(Key: English, Bahasa Malaysia, Tamil)

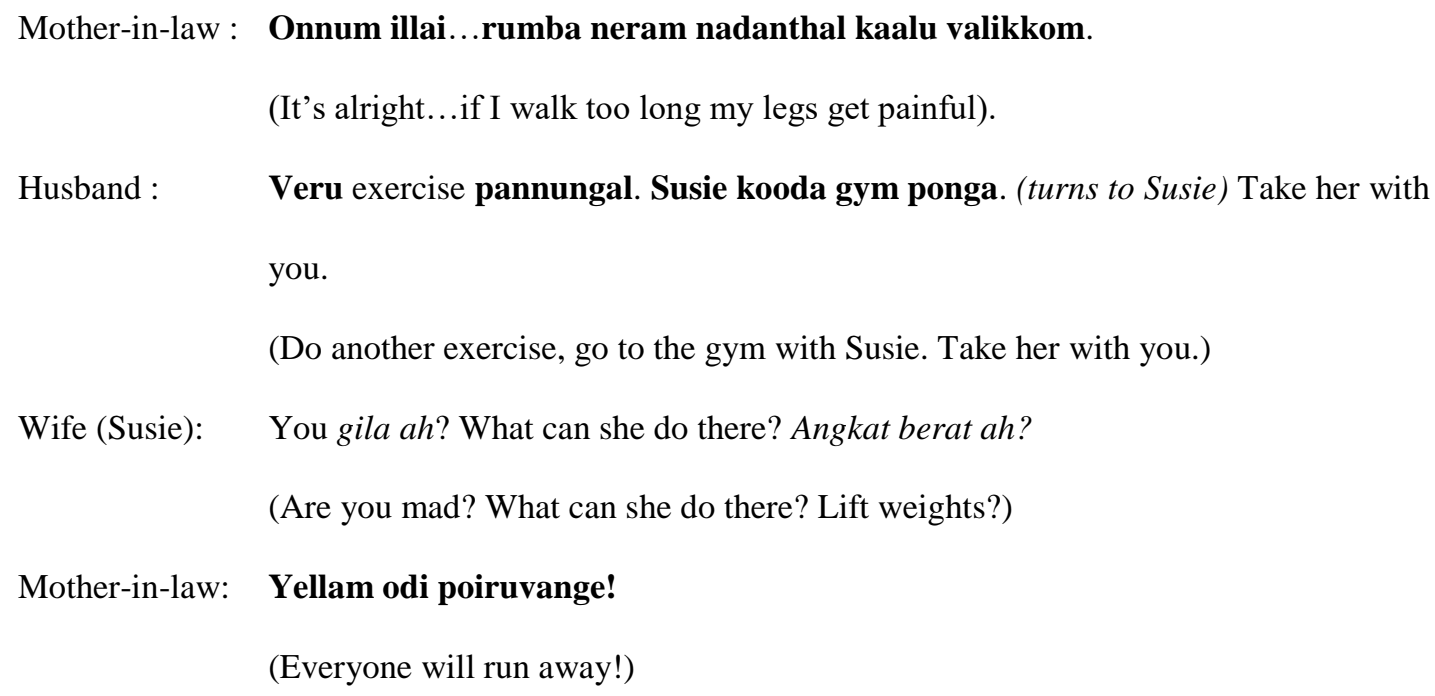

While analyses of Bahasa Rojak such as these adhere to essentialised views of language in contact similar to Manglish, Pennycook (2014) explains that Bahasa Rojak was traditionally 'whatever language resources were used to buy and sell, barter and trade' (p. 6) with an emphasis on communication. Today, Pennycook (ibid) theorises Bahasa Rojak as an example of metrolingualism because when talking across ethnic, political, and cultural divides, 'it becomes clear that the potential resources available to people may be extraordinarily diverse' (p. 8). The notion is that rather than Malaysians mixing different languages in any predictable way, Bahasa Rojak is strategic, flexible and resourceful communication that emphasises meaning-making above form.

The paper now analyses how language and multilingualism are understood by language users themselves in Malaysia. The focus is on whether and how essentialised or nonessentialised views of language that underpin languages, mother tongues and languaging 
This is an Accepted Manuscript of an article published by Cambridge University Press,

Language in Society, available at https://www.cambridge.org/core/journals/language-insociety/article/mother-tongues-and-languaging-in-malaysia-critical-linguistics-under-criticalexamination/63E9315695008B98517AA546BF6C5F54

are relevant to how Malaysians themselves rationalise their sociolinguistic environment through their own linguistic epistemologies.

\section{Theory and method}

Beyond the theoretical conceptualisations of mother tongue and languaging offered above, the paper also draws on Schiffman's (1995b; 2006) notion of linguistic culture coupled with Canagarajah's (2005b) call to reclaim local knowledge in sociolinguistic research. Just as linguistic culture refers to 'ideas, values, beliefs, attitudes, prejudices, myths, religious strictures, and all other cultural "baggage" that speakers bring to their dealings with language from their culture' (Schiffman 2006:112), Canagarajah (2005a) argues that we ought to investigate the claimed sociolinguistic knowledge of communities so that 'social practices, communicative conventions, linguistic realities and knowledge paradigms' (p. xi) can be used by academia to better understand local sociolinguistic phenomena. The combination of linguistic culture and localising knowledge creates the opportunity to investigate epistemologically-driven discourses of language users that explain to what extent languages, mother tongue and languaging are relevant to those discourses.

A series of 24 focus group discussions were held with Malay, Chinese, and Indian undergraduate students, all in their early 20s, at public and private universities across peninsula Malaysia in Kuala Lumpur, Bangi, Penang, Kota Bharu, and Kuala Terengganu. As volunteer participants, students were grouped by self-identified ethnicity, upon the advice from the host universities that this is socially more appropriate. This also minimised the risk of Malays inadvertently perceiving non-Malays as questioning the supremacy of their language and culture, which is forbidden under Malaysian law. Each group comprised four 
This is an Accepted Manuscript of an article published by Cambridge University Press,

Language in Society, available at https://www.cambridge.org/core/journals/language-insociety/article/mother-tongues-and-languaging-in-malaysia-critical-linguistics-under-criticalexamination/63E9315695008B98517AA546BF6C5F54

to six students. A total of ten focus group discussions were held with Malay students, nine with Chinese students and five with Indian students. Students were recruited with the assistance of host institutions.

The discussions took a folk-linguistic approach (Preston 2005; Preston 2011) in that they especially investigated what the students claimed to know or presume as facts and logics - in epistemic terms - about various language phenomena in Malaysia. This used Albury's (2014; 2016a) folk linguistics of language policy paradigm but shifted the focus from language policy to epistemic discourses about multilingualism more broadly. This also meant the students were from various majors other than linguistics, including business, accounting, English, Malay literature, and forensic science. The discussions were semistructured, held in English, and began by asking students to describe the language situation in Malaysia in general terms. As predicted, almost all groups raised the terms Manglish and Bahasa Rojak as linguistic phenomena, and when this occurred I asked the students to elaborate and define these terms. Where this did not occur naturally in the discussions, I told the students I had heard of Manglish and Bahasa Rojak, and wondered if they could explain these concepts. The opening question typically led to descriptions of ethnic diversity and its corresponding languages. The students were then asked if Malaysia operates a language policy, and almost all responses included the government's provision of primary-level Mandarin and Tamil-medium education. Students were also asked for their opinion on news reports of Malay nationalists calling for the abolishment of these schools (Malay Mail Online 2015). This combined approach to the focus group discussions ensured that the line of questioning itself did not inadvertently prompt the students to discuss language in either 
This is an Accepted Manuscript of an article published by Cambridge University Press,

Language in Society, available at https://www.cambridge.org/core/journals/language-insociety/article/mother-tongues-and-languaging-in-malaysia-critical-linguistics-under-criticalexamination/63E9315695008B98517AA546BF6C5F54

essentialised or nonessentialised terms, however, responses to the final question could host discourses about mother tongues.

Holding group discussions responds to Blackledge's (2000) view that language ideologies - including shared epistemologies - are best identified and retrieved through interaction. This is because collective beliefs are realised discursively and group interaction allows a belief or epistemology to be debated, refined and endorsed by a collective. Analysis used a content-oriented discourse analytical approach for folk linguistic conversations (Preston 2011). This allows for an examination of what is overtly said, as well as what is implicitly presupposed within epistemic positions, with a focus on qualitative argumentation. To investigate how the students related to the principles underpinning language, languaging and mother tongues, analysis now focuses specifically on how the students discussed and described Manglish and Bahasa Rojak, as well as mother tongues, in respect to their own language profiles and language-in-education. Excerpts from the discussions are literal, and have not been edited for grammar.

\section{Manglish as essentialised code-switching}

The folk linguistic discourses of the focus groups all defined Manglish as the mixing of two discreet languages in some way. In some cases, Manglish was seen as its own essentialised variety of English reminiscent of Wee's (2014) description of Singlish in Singapore. For example, when asked what Manglish is, an Indian student explained that 'it's more a term as Malaysia English, Manglish. Like European English accent itself is different, and for us Malaysian, our accent is different' and a Malay student explained that 'Manglish has not been recognised yet, only Singlish is being recognised'. Others reiterated that Manglish is used 
This is an Accepted Manuscript of an article published by Cambridge University Press,

Language in Society, available at https://www.cambridge.org/core/journals/language-insociety/article/mother-tongues-and-languaging-in-malaysia-critical-linguistics-under-criticalexamination/63E9315695008B98517AA546BF6C5F54

only colloquially, adding 'Manglish is quite often used in social media such as Facebook, twitter or Instagram too' (Malay student) and that it is used for 'unofficial' situations (Chinese student).

More commonly, the students described Manglish with an emphasis on systems and form, rather than on function and meaning, in terms akin to the code-switching work carried out in Malaysia discussed earlier (David 2003; Don 2003; Lau \& Ting 2013). All the Malay and Indian groups, and most Chinese groups, defined Manglish as speaking in either English or Malay and prescribing to its syntactic rules, but using lexica from the other language. Malay students explained 'for example, like in English, eat we call it eat, in Malay we call it makan, so like I ask you, where you want to go for makan later?'. Indian students agreed, explaining 'I find that it's a combination of both. Your main language could be Malay then you use English or your main language could be in English then you insert Malay words'. In the same group, another student raised a parallel with Tanglish, explaining 'actually like Manglish, Tanglish, we mix it together. We don't actually speak English alone or Tamil alone. Basically we mix languages over here even at university. But you also can see we actually speak a combination of English and Malay mostly'. Others defined Manglish solely as affixing the Malay particle lah to a sentence. Lah is indeed typical in Malaysian conversation with its meaning depending on context, ranging from creating emphasis, showing light-heartedness, or displaying ill-temperedness (Goddard 1994). A Chinese group of business students offered the example 'let's go eat lah', explaining '[Lah] is a Malay word but we mix it in the English: I don't want lah, don't like that lah'. Interestingly, some Chinese students argued that Manglish is 'Mandarin mix English', whereby the Man of Manglish denotes Mandarin. Other Chinese students were dubious about an exact definition 
This is an Accepted Manuscript of an article published by Cambridge University Press,

Language in Society, available at https://www.cambridge.org/core/journals/language-insociety/article/mother-tongues-and-languaging-in-malaysia-critical-linguistics-under-criticalexamination/63E9315695008B98517AA546BF6C5F54

of Manglish, but leant towards including Mandarin in some way. For example, 'Manglish is, I don't know how to say, it's like more influence of Mandarin'.

However, two Malay groups defined Manglish as code-switching not at the intrasentential level, but within conversations. In one case, they defined Manglish as a speaker offering a sentence in two discreet languages, explaining 'like if we say in English where to eat? and then in Malay we say makan pergi mana? We just follow the arrangement to Malay'. In the second case, students defined Manglish as each interlocutor committing to one language, such that dialogue becomes bilingual, whereby Manglish is what sociolinguists might see as conversational code-switching:

Student 3: $\quad$ Example in a family: maybe husband is Malay, wife Chinese or Indian, so when they talk with the children, the husband talk Malay at the children and the wife talk English.

Student 2: $\quad$ It becomes Manglish.

In any case, the students agreed that Manglish is about switching between two defined languages at some level of communication, and most saw this as rule-governed. Whether this rule be that Manglish amounts to a new essentialised code, affixing the particle lah to a sentence, sequential interpretation, or language choices determined by the linguistic identities of speakers, Manglish was constructed as language practice that is definable and predictable. Manglish, as contact between two essentialised languages, was pertinent to their understandings of Malaysian sociolinguistics and local language practices.

\section{Bahasa Rojak as non-essentialised languaging}

Although the students generally defined Manglish as type of Bahasa Rojak, they mostly described Bahasa Rojak in non-essentialised terms akin to languaging. Rather than focusing 
This is an Accepted Manuscript of an article published by Cambridge University Press,

Language in Society, available at https://www.cambridge.org/core/journals/language-insociety/article/mother-tongues-and-languaging-in-malaysia-critical-linguistics-under-criticalexamination/63E9315695008B98517AA546BF6C5F54

on systems, forms, or how two discreet languages merge, Bahasa Rojak was described as communication, meaning-making across ethnolinguistic divides, and interethnic inclusion. Only a small minority of students described Bahasa Rojak in the essentialised terms they used when describing Manglish. For example, a Malay student explained that 'I think Manglish alone is the Malay language and English, and then you mix up more languages so it becomes Bahasa Rojak'. Others relied on essentialised terms to describe Bahasa Rojak, but their discussions focused on function rather than form, revealing a nonessentialised bias. This was expected because the vocabulary available to non-linguists in describing complex phenomena is limited (Preston 1996). For example, after saying Bahasa Rojak includes different languages, a Malay student added that Bahasa Rojak 'can be anything'. When prompted to further clarify this, the student explained

In Malaysia [we have] so many races, religions and cultures. So I think that has affected us to speak because this is the way how we connect with people in Malaysia. If you just focus on yours, how can you be connected with the others? So this is how the way we attract them to be one of the group.

The notion, then, is that Bahasa Rojak is as culture of language practice that fosters interethnic inclusiveness. This same group even argued that Bahasa Malaysia fails as a national language because of the more expansive role Bahasa Rojak plays in interethnic communication. Similar positions were expressed by other ethnic groups. Chinese students explained that Bahasa Rojak helps to 'build up many cultures' and Indian students claimed that Bahasa Rojak 'is like bringing us together' to index an interethnic linguistic identity, whereby 'Malaysians use that term [Bahasa Rojak] to define our language'.

Unlike their descriptions of Manglish that focused on the structural results of language contact, almost all groups agreed that Bahasa Rojak is fluid rather than rule-driven 
This is an Accepted Manuscript of an article published by Cambridge University Press,

Language in Society, available at https://www.cambridge.org/core/journals/language-insociety/article/mother-tongues-and-languaging-in-malaysia-critical-linguistics-under-criticalexamination/63E9315695008B98517AA546BF6C5F54

communication that draws on multilingual resources to facilitate communication. An Indian group explained that Bahasa Rojak improves communication between rather than within ethnolinguistic groups, illustrated by a reference to fostering understanding:

Student 1: $\quad$ Yea, and maybe, maybe some people, like, when they are communicating with their friends, they use maybe, like, two languages or maybe one, some of us we just mix up languages, like a few languages and then communicate.

Student 3: It can be any language. And it comes out to be a sentence, and that sentence is not universal, but is understood commonly in Malaysia.

This especially meant that each manifestation of Bahasa Rojak is different, determined by the linguistic resources and proficiencies available within a conversation group, to facilitate communication. This is, as discussed earlier, akin to what Pennycook (2010) calls metrolingualism. Students also explained that Bahasa Rojak changes by geographic area because local ethnic compositions vary. For example, Sarawak and Sabah on Borneo, and Kelantan and Terengganu on the peninsula's east coast, have extremely small Indian populations, their Chinese communities typically use different Chinese varieties to western Malaysia, and the local dialect of Malay is significantly different to standard Malay. Accordingly, as Malay students explained 'maybe we here, Terengganu, Kelantan, have own Bahasa Rojak, so if you go to Kuala Lumpur, you go to Selangor, you go to Pahang, you go to Johor, to the west, they have our own Bahasa Rojak'.

The emphasis on meaning-making was expressed by Malay students who agreed that Bahasa Rojak functions 'like idioms'. Students across all ethnic groups emphasised their own truncated linguistic repertoires and the need to draw on their own and their conversation partner's linguistic resources, rather than adhere to any specific language. For example, an Indian group explained that 'as I said, people can't speak fluently in one language, they use 
This is an Accepted Manuscript of an article published by Cambridge University Press,

Language in Society, available at https://www.cambridge.org/core/journals/language-insociety/article/mother-tongues-and-languaging-in-malaysia-critical-linguistics-under-criticalexamination/63E9315695008B98517AA546BF6C5F54

words and phrases from other languages to replace those words'. A Chinese group explained the following:

Student 2: $\quad$ Like, let's say we are speaking English and then there is one word that I don't know what is it in English, then I will speak Mandarin. So, as long as the other person knows what it means in Mandarin, so we will just...

Student 3: $\quad$ Continue.

Researcher: What if the other person doesn't know the word?

Student 2: $\quad$ Then we will explain to them.

Student 4: $\quad$ Yeah.

Student 3: $\quad$ But usually they will just carry on.

Student 5: $\quad$ Yeah, let's say she is Malay, we will change that word to Malay.

Student 4: $\quad$ Because all of the languages are already a norm to us. So we will use whatever word we find is apt for the situation, then we will just include it regardless of what language it is.

Another Chinese group made a similar argument, as shown in the following:

Student 2: $\quad$ I grew up with multiple races, like the Malay, Indian, and when we gather together, when we are like playing games, we speak like mixed language, like rojak, it's called rojak lah. In Penang, you speak in Hokkien, then suddenly you change topic you speak in Malay, because the Malay people need to understand what I'm talking.

Then, there are Indians speaking Tamil, and then it's like something like natural to us, that we keep talking, talking, and it doesn't feel formal, we feel like very fun.

Student 3: $\quad$ Yeah.

For other students, Malaysian linguistic culture allows for a speaker to introduce lexica from one's own heritage language into interethnic conversation, facilitated by Bahasa Rojak. This contrasts with accommodating another person's linguistic repertoire, but ensures one's own linguistic heritage is represented in interethnic conversation with the understanding that 
This is an Accepted Manuscript of an article published by Cambridge University Press,

Language in Society, available at https://www.cambridge.org/core/journals/language-insociety/article/mother-tongues-and-languaging-in-malaysia-critical-linguistics-under-criticalexamination/63E9315695008B98517AA546BF6C5F54

certain terms from across Malaysia's languages have entered into the national vocabulary. This is shown in the following dialogue amongst Indian students who claimed they will use the Tamil term macha (discussed earlier) and expect Chinese-Malaysians to introduce Chinese words, such as tabao (take away food):

Student 1: $\quad$ Like for example, if we are going out for lunch, a friend, maybe a Chinese friend, you are like, usually boys use this term, like um, hey macha, let's go...

Student 2: $\quad$ For lunch.

Student 1: $\quad$ Let's go for lunch. Then the guy will be like you want to eat here or tabao? Tabao is Chinese word and that macha is Tamil word. Just like mixture, and everyone basically understand. The easy language.

In any case, the students emphatically defined Bahasa Rojak as not bound to the prescriptive rules of any essentialised language, but guided by multilingual repertoires in multi-ethnic settings. The students asserted that unlike monolingual conversations, or the form-focused code-switching they described for Manglish, Bahasa Rojak is about communication. For them, Bahasa Rojak is language but not a language, instead akin to what sociolinguists see as languaging.

\section{The cultural pertinence of mother tongues}

Just as Bahasa Rojak as unessentialised languaging was positioned as intrinsic to Malaysian linguistic culture, the students' folk linguistic discourses revealed that essentialised mother tongues - as the language of an imagined community - are also indispensable. This, in itself, is not surprising as Pennycook (2002) predicts. He argues that not only might the notion of mother tongues serve as a tool in language policy and identity-building processes in multilingual societies, but it is also a hangover of European colonial projects that divided and 
This is an Accepted Manuscript of an article published by Cambridge University Press,

Language in Society, available at https://www.cambridge.org/core/journals/language-insociety/article/mother-tongues-and-languaging-in-malaysia-critical-linguistics-under-criticalexamination/63E9315695008B98517AA546BF6C5F54

ruled ethnic groups through essentialism. This indeed holds true for Malaysia. For example, when asked about multilingualism in Malaysia, a Malay student explained that each ethnic group corresponds to a mother tongue:

There are three main ethnicity in Malaysia: Malay, Indian and Chinese. So each of the group has their own mother language, for Malay Bahasa Melayu, and then for Chinese, they speak Mandarin...For the Indians, they speak Tamil.

Others relied on mother tongues in justifying language rights, especially the provision of mother tongue-medium education. When discussing reports of Malay nationalists seeking to abolish Chinese and Indian schools, a Chinese student emphatically argued 'it's our identity, we should protect our language like we can learn other language but we should protect our own mother tongue also' and a Malay student argued

By having the variety of schools, actually it preserves the multilingualism in Malaysia. If we get rid of the Jenis Kebangsaan [vernacular schools], it's slowly going to be like Indonesia. Like if you are Chinese in Indonesia, you still have Indonesian name, you have to learn Indonesian Bahasa and you can only practice your mother tongue in your house.... our country should work on how to preserve the multilingual, the multicultural.

However, Pennycook's (2003) critical perspective recalls that the mother tongue, as used in these examples, is an ideological construct. This is also true in Malaysia, where home languages are many more than only Malay, Mandarin, and Tamil as typically identified by the students vis-à-vis Malaysian policy and education. Therefore we should, Pennycook argues, avoid 'overarching statements about the mother tongue' (p. 23) and work contextually to consider the relevance of mother tongues in the cultures, politics and minds of local communities. The discussions indeed revealed that for Malaysian youth, the notion that they 
This is an Accepted Manuscript of an article published by Cambridge University Press,

Language in Society, available at https://www.cambridge.org/core/journals/language-insociety/article/mother-tongues-and-languaging-in-malaysia-critical-linguistics-under-criticalexamination/63E9315695008B98517AA546BF6C5F54

themselves hold a mother tongues is central to their linguistic identity and, as I will argue, indispensable to Malaysian sociolinguistics and linguistic cultures.

Malay discourses about Bahasa Malaysia as a mother tongue were rare, whereas discourses amongst Indian and Chinese students about their mother tongues were complex. For them, the mother tongue is not defined as the language an individual is raised speaking. Instead, an individual's mother tongue is the heritage language of their ethnic community, even if the individual is not proficient in the language. This, as an epistemological feature of Malaysian linguistic cultures, is no doubt informed by collective memories of migration to Malaysia, and the continued positioning of non-Malays as pendatang. This presumably encourages Chinese- and Indian-Malaysians to identify linguistically in respect to the ancestral homeland. However, beyond mother tongues being relevant to the language narratives of individuals, Indian and Chinese epistemologies of mother tongue were different and are now dealt with separately.

Indian students understood their mother tongue to be the language of their ancestors. Most commonly, this was discussed in the context of widespread shift in Indian communities from raising children in an Indian language to English. Rather than positioning English as the mother tongue of children affected by this language shift, the Indian students explicitly argued that the mother tongue of an Indian-Malaysian remains the Indian heritage language, including where a person has not acquired proficiency in that language. For example, an Indian student who was raised in English described his intention to start studying Tamil. The following dialogue ensued:

Researcher: $\quad$ Yeah, so why do you want to learn Tamil?

Student 4: $\quad$ This is my mother tongue. 
This is an Accepted Manuscript of an article published by Cambridge University Press,

Language in Society, available at https://www.cambridge.org/core/journals/language-insociety/article/mother-tongues-and-languaging-in-malaysia-critical-linguistics-under-criticalexamination/63E9315695008B98517AA546BF6C5F54

Indian students also made a distinction between mother tongues and first languages such as in the following:

Researcher: $\quad$ I have been reading that the Tamil language in Malaysia is starting to disappear. Is
that true?
Student 1: $\quad$ Actually it's very subjective...let's say at home, actually children start learning
language from their parents, they actually start teaching when they are small, so
sometimes the parents might not teach them Tamil. So English might be their first
language. So they start to speak in English, which mean slowly they forget their
mother tongue or they don't actually see the importance, because there are people
even on our campus, you can see that they are Indians, their mother tongue is Tamil,
but not necessarily, they do not know how to speak Tamil because they did not learn
it from their home.

Here, Tamil remains the mother tongue of Tamil families who raise their children in English as a first language. The notion, then, is that mother tongues are the languages of ancestors, and this remains central to the ethnolinguistic identity of individuals in future generations even if proficiency is not transmitted. In some cases, Indian students described the tension that exists between non-proficiency in a mother tongue and the symbolism the mother tongue holds in religion. A Punjabi student, who claimed to indeed speak Punjabi at home, reflected on her peers who were raised in English, explaining

Sometimes when I go to the temple right, you are actually supposed to speak your mother tongue, let's say me, Punjabi. But no....they speak English. It is like they don't care about their mother tongue at all.

Chinese-Malaysian definitions of mother tongue - expressed both explicitly and implicitly - were different yet again. Chinese students explained that the mother tongue of all Chinese-Malaysians is in fact Mandarin. Migration from southern China brought many 
This is an Accepted Manuscript of an article published by Cambridge University Press,

Language in Society, available at https://www.cambridge.org/core/journals/language-insociety/article/mother-tongues-and-languaging-in-malaysia-critical-linguistics-under-criticalexamination/63E9315695008B98517AA546BF6C5F54

Chinese heritage languages to Malaysia, but not Mandarin. Nonetheless, Chinese students who were raised in a local Chinese language, such as Cantonese, Hokkien or Hakka, claimed Mandarin to be their mother tongue without giving any status to their own heritage language. This is illustrated in the following dialogue about why Mandarin is used as a lingua franca among Chinese-Malaysians and in Chinese-medium education:

\footnotetext{
Researcher: So why is it Mandarin that you speak across Chinese groups? You know Cantonese is also a big language, why not Cantonese?

Student 2: $\quad$ Um, let's say from China, they put Mandarin as their mother tongue.

Researcher: Why not teach in Hokkien or Cantonese?

Student 1: $\quad$ Because we are Chinese so we must learn our mother tongue.
}

For these students, it appears Mandarin holds such political, social, economic, or symbolic prestige that it counts as the only Chinese language that can index a united Chinese ethnic identity. This renders the non-Mandarin varieties lower on a linguistic hierarchy among Chinese-Malaysians as a collective. This was summed up by a student's explanation that 'like, under Mandarin there is Cantonese, Hakka, Hokkien, Teochew, Foochow'. The reasons for this orientation are likely many. Beijing and Singapore-based language politics may have had influence in Malaysia, too. China indeed positions Beijing-accented Mandarin known as Putonghua (general language) as the unifying language of its people (Spolsky 2004). Singapore's Speak Mandarin Campaign promoted Mandarin as an intra-Chinese lingua franca, recognising the political status of Mandarin in China. It is also possible that cultural ideas of social collectivism, that are common to Chinese cultures (Koch \& Koch, 2007), prompt Chinese to identify - in this case linguistically - in a way that maximises ethnic inclusion. However, Mandarin is also seen as rich with literary and cultural tradition, and reminds the Chinese diaspora that the language is part of an ancient civilisation. This, it 
This is an Accepted Manuscript of an article published by Cambridge University Press,

Language in Society, available at https://www.cambridge.org/core/journals/language-insociety/article/mother-tongues-and-languaging-in-malaysia-critical-linguistics-under-criticalexamination/63E9315695008B98517AA546BF6C5F54

is argued, constitutes 'a deep and strong psychic force' (Lee 1984 in Teo 2005:123) amongst ethnic Chinese that seems to also be at play in Malaysia, as shown in the following dialogue:

Student 2: $\quad$ Chinese, Mandarin, is our mother language. So we cannot refuse to learn it, yeah.

Researcher: Yeah?

Student 2: We have to respect it because we've brought it down for 5,000 years and we cannot just let it die.

However, this enthusiasm for Mandarin as a mother tongue meant the students described their first languages - such as Cantonese and Hokkien - as dialects of Mandarin. Although this is scientifically erroneous (Ramsey 1987), the belief was held unanimously across the focus groups, as illustrated in the following:

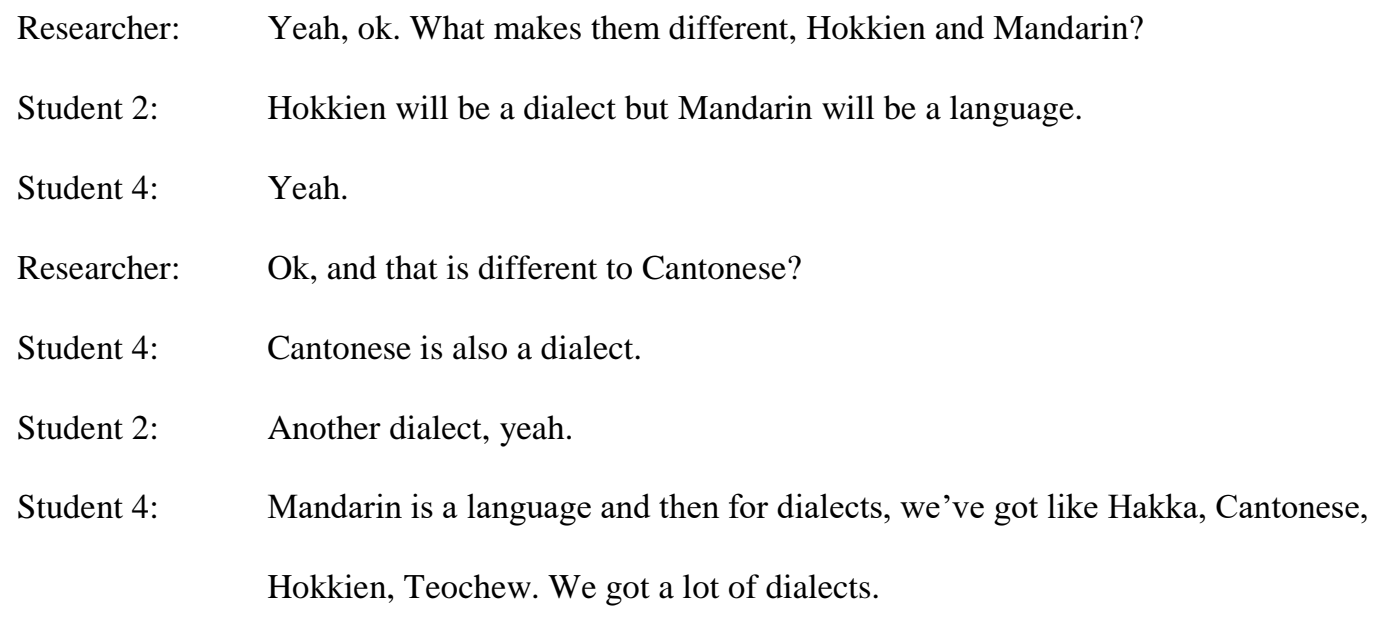

By defining non-Mandarin varieties as dialects of Mandarin, the students constructed a less heterogeneous, Mandarin-led linguistic situation both within China and within the diaspora. Doing so arguably legitimises, from their perspective, their ethnic identity as Chinese. If the most authentic Chinese identity implies identification with Mandarin as a mother tongue, then positioning their own heritage languages as dialects of Mandarin is practical in constructing and validating that ethnic identity. In any case, Mandarin plays a crucial role in Chinese linguistic culture in Malaysia, in turn rationalising why Chinese-Malaysians use 
This is an Accepted Manuscript of an article published by Cambridge University Press,

Language in Society, available at https://www.cambridge.org/core/journals/language-insociety/article/mother-tongues-and-languaging-in-malaysia-critical-linguistics-under-criticalexamination/63E9315695008B98517AA546BF6C5F54

Mandarin as a lingua franca, and justifying Mandarin, as an essentialised language, in Chinese-medium education as a language policy.

\section{Conclusion}

Pennycook was right to warn that in our enthusiasm for critical linguistics - especially our shifting focus from essentialised views of language to complex linguistic repertoires and meaning-making through languaging in our analyses of linguistic practice - we ought not to throw the baby out with the bathwater. This paper sought to place this critical shift under a critical lens by examining it face-to-face with what the paper termed the local-knowledge turn in sociolinguistics. This turn increasingly emphasises local knowledge so that sociolinguistic phenomena can be investigated and analysed in respect to the epistemologies and world views of those we research. Doing so meant critically examining whether, and how, the principles, concerns, and enthusiasm underlying the terms mother tongue, languages and languaging (and the many postmodern terms related to languaging), which have been developed in the global North and occupy academic thinking, hold relevance in epistemologies and linguistic cultures of the global South.

The case of Malaysia provides ample evidence that all these concepts can concurrently hold crucial roles in how language users understand their own sociolinguistic world. Ideas inherent to languaging, developed and refined in academia over the last decade, are already firmly embedded in Malaysian linguistic culture to describe local linguistic behaviour. Bahasa Rojak fills this role, the function of which was enthusiastically described by Malaysian youth as the fluid exploitation of multilingual resources, specific to the context and ethnic identities of those present in a conversation, to foster mean-making across 
This is an Accepted Manuscript of an article published by Cambridge University Press,

Language in Society, available at https://www.cambridge.org/core/journals/language-insociety/article/mother-tongues-and-languaging-in-malaysia-critical-linguistics-under-criticalexamination/63E9315695008B98517AA546BF6C5F54

ethnolinguistic divides. For these youth, Bahasa Rojak can have infinite manifestations because its genesis is the linguistic resources of speakers at any given time and location, rather than an essentialised view of any language, with a focus on function rather than form. Its role in fostering interethnic inclusiveness in a political environment that has hierarchised race means Bahasa Rojak plays a crucial role not only in Malaysian sociolinguistics, but also in Malaysian sociopolitical life. However Manglish, also a phenomenon of language contact that falls under the umbrella term Bahasa Rojak, was indeed described in essentialised terms. The students often gave resolute definitions of Manglish with a focus on form rather than function, such as that it was defined as a new language, as comprising a Malay or English substrate (or Mandarin and English, in the view of Chinese students) and incorporating lexica from a donor language, or as specific linguistic patterns or rules. Although the students offered different ideas on what these patterns or rules are, they all nonetheless relied on an essentialised view of language to explain Manglish that they did not rely on for Bahasa Rojak. Manglish, as the merging of two discreet languages, was perceived as uniquely Malaysian and is omnipresent in their metalinguistic discourses about language in Malaysia, meaning it is central to their understanding of their own linguistic environment and their sociolinguistic identities as Malaysians.

By the same token, the concept of mother tongue also remained central to the students' discourses. One the one hand, this confirmed views in earlier scholarship that despite the critical turn in linguistics, mother tongues are strategically useful outside ethnographic analyses of linguistic behaviour because they can support ethnic identification, language policy, language education, and language rights. Far beyond this, however, this paper also showed that epistemic conceptualisations of mother tongues take on non-western 
This is an Accepted Manuscript of an article published by Cambridge University Press,

Language in Society, available at https://www.cambridge.org/core/journals/language-insociety/article/mother-tongues-and-languaging-in-malaysia-critical-linguistics-under-criticalexamination/63E9315695008B98517AA546BF6C5F54

meanings amongst Chinese- and Indian-Malaysians which cement their pertinence in constructing personal relationships to language and history in contemporary Malaysia. Whereas the West sees mother tongues as the language an individual is raised in and forms a lasting bond with, Malaysians see mother tongues as the language of an ethnic or ethnolinguistic collective, even if an individual is not proficient in it. Accordingly, a mother tongue is transmitted intergenerationally as an identity, even if not in linguistic practice. Indian students therefore explained that Indian-Malaysians who speak English as a first language nonetheless retain an Indian heritage language as their mother tongue, as this is the language of their ancestors. Chinese students explained that Mandarin is the mother tongue of all Chinese-Malaysians, despite the fact that Mandarin was not a heritage language brought to Malaysia through Chinese migration, and that many Chinese-Malaysians only learn Mandarin through the school system. For them, Mandarin is the symbolic language of Chinese identity and unity, and this belief was so steadfast that the students argued that their unrelated heritage languages - such as Cantonese and Hokkien - are simply dialects of Mandarin.

Doing away with an essentialised view of language would not only disregard how Malaysians themselves understand and engage their linguistic world, but would radically displace non-western views. This is not to argue against the valuable postmodern theoretical developments made in de-essentialising language when analysing linguistic behaviour, as this no doubt liberates complex multilingual profiles and practice from the hegemony of essentialised languages. Indeed, this is vital to understanding communication in Malaysia and is cemented in local Malaysian metalinguistic commentary and linguistic identity. The point, however, is much broader. It is clear that the idea of mother tongues is still 
This is an Accepted Manuscript of an article published by Cambridge University Press,

Language in Society, available at https://www.cambridge.org/core/journals/language-insociety/article/mother-tongues-and-languaging-in-malaysia-critical-linguistics-under-criticalexamination/63E9315695008B98517AA546BF6C5F54

strategically important, but this can co-exist peacefully with languaging in sociolinguistic data. As this paper showed, essentialised and nonessentialised views of language, as they manifest in the terms such as mother tongues and languaging vis-à-vis local linguistic cultures and local metalinguistic knowledge, can be complementary. Therefore, in as far as scholarship also calls for the investigation of local knowledge and epistemology in sociolinguistics research, it would be remiss of us to exclude essentialised views of language from any holistic understanding of language in society in the name of critical linguistics.

\section{Acknowledgements}

I would like to express my profound thanks to Professor Bente Ailin Svendsen at the University of Oslo's Center for Multilingualism in Society across the Lifespan whose subject matter expertise on languaging, and encouragement for scholarship that challenges and transcends western epistemologies of language, helped guide this research.

\section{Bibliography}

Ag, Astrid \& Jørgensen, Jens Normann (2013). Ideologies, norms, and practices in youth polylanguaging. International Journal of Bilingualism 17(4):525-539.

Albury, Nathan John (2014). Introducing the Folk Linguistics of Language Policy. International Journal of Language Studies 8(3):85-106.

Albury, Nathan John (2016a). Defining Māori language revitalisation: A project in folk linguistics. Journal of Sociolinguistics 20(3):287-311.

Albury, Nathan John (2016b). The power of folk linguistic knowledge in language policy. Language Policy. doi:10.1007/s10993-016-9404-4

Albury, Nathan John \& Aye, Khin Khin (2016). Malaysia's national language policy in international theoretical context. Journal of Nusantara Studies 1(1):71-84.

Androutsopoulos, Jannis (2015). Networked multilingualism: Some language practices on Facebook and their implications. International Journal of Bilingualism 19(2):185-205. 
This is an Accepted Manuscript of an article published by Cambridge University Press,

Language in Society, available at https://www.cambridge.org/core/journals/language-in-

society/article/mother-tongues-and-languaging-in-malaysia-critical-linguistics-under-criticalexamination/63E9315695008B98517AA546BF6C5F54

Auer, Peter (ed.) (1998). Code-switching in conversation: Language, interaction and identity. New York: Routledge.

Blackledge, Adrian (2000). Monolingual ideologies in multilingual states: Language, hegemony and social justice in Western liberal democracies. Estudios de Sociolingüística 1(2):25-45.

Blommaert, Jan (2010). The sociolinguistics of globalization. Cambridge: Cambridge University Press.

Blommaert, Jan, Leppänen, Sirpa \& Spotti, Massimiliano (2012). Endangering multilingualism. In S Leppänen J Blommaert, P Pahta, T Räisänen (ed.), Dangerous multilingualism: Northern perspectives on order, purity and normality 1-21. London: Palgrave Macmillan UK.

Canagarajah, Suresh (2005a). Introduction. In A Suresh Canagarajah (ed.), Reclaiming the local in language policy and practice xiii-xxx. Mahwah: Lawrence Erlbaum.

Canagarajah, Suresh (2005b). Reconstructing local knowledge, reconfiguring language studies. In A Suresh Canagarajah (ed.), Reclaiming the local in language policy and practice 3-24.

Mahwah: Lawrence Erlbaum.

Coluzzi, Paolo, Riget, Patricia Nora \& Xiaomei, Wang (2013). Language vitality among the Bidayuh of Sarawak (East Malaysia). Oceanic Linguistics 52(2):375-395.

David, Maya Khemlani (2003). Role and functions of code-switching in Malaysian courtrooms. Multilingua: Journal of Cross-Cultural and Interlanguage Communication 22(1):5-20.

David, Maya Khemlani, Kuang, Ching Hei, McLellan, James \& Fatimah, Hashim (2009). Functions of code switching in the family domain in Malaysia. In M. K. David, Kuang, C. H., McLellan, J., Fatimah, H. (ed.), Code switching in Malaysia 3-28. Frankfurt: Peter Lang.

David, Maya Khemlani, Naji, Ibtisam M. H. \& Kaur, Sheena (2003). Language maintenance or language shift among the Punjabi Sikh community in Malaysia? International Journal of the Sociology of Language 2003(161):1-24.

Department of Statistics Malaysia (2010). Population Distribution and Basic Demographic Characteristic Report 2010

Don, Zuraidah Mohd (2003). Language-dialect code-switching: Kelantanese in a multilingual context. Multilingua: Journal of Cross-Cultural and Interlanguage Communication 22(1):21-40.

Errington, Joseph J (1998). Shifting languages. Cambridge: Cambridge University Press.

Flores, Nelson \& Schissel, Jamie L (2014), Dynamic bilingualism as the norm: Envisioning a heteroglossic approach to standards-based reform. TESOL Quarterly 48:454-479.

Fowler, Carol A. \& Hodges, Bert H. (2011). Dynamics and Languaging: Toward an Ecology of Language. Ecological Psychology 23(3):147-156.

Frith, Tabitha (2000). Ethno-religious identity and urban Malays in Malaysia. Asian Ethnicity 1(2):117-129. 
This is an Accepted Manuscript of an article published by Cambridge University Press,

Language in Society, available at https://www.cambridge.org/core/journals/language-in-

society/article/mother-tongues-and-languaging-in-malaysia-critical-linguistics-under-criticalexamination/63E9315695008B98517AA546BF6C5F54

García, Ofelia (2009). Education, multilingualism and translanguaging in the 21 st century. In T Skutnabb-Kangas, R Phillipson, A K Mohanty \& M Panda (eds.), Social justice through multilingual education 140-158. Bristol: Multilingual Matters.

Gill, Saran Kaur (2013). Language policy challenges in multi-ethnic Malaysia. Dordrecht: Springer.

Goddard, Cliff (1994). The meaning of lah: Understanding "emphasis" in Malay (Bahasa Melayu). Oceanic Linguistics 33(1):145-165.

Goebel, Zane (2012). Enregisterment, communities, and authenticity: Watching Indonesian teledramas. Journal of Linguistic Anthropology 22(2):E1-E20.

Goebel, Zane (2014). Doing leadership through signswitching in the Indonesian bureaucracy. Journal of Linguistic Anthropology 24(2):193-215.

Gumperz, John (1964). Linguistic and social interaction in two communities. American Anthropologist 66(6, Part 2): 137-153.

Gumperz, John \& Hymes, Dell (eds.) (1972). Directions in sociolinguistics: The ethnography of communication. New York: Holt, Rinehart, \& Winston.

Hamayotsu, Kikue (2014). Towards a more democratic regime and society? The politics of faith and ethnicity in a transitional multi-ethnic Malaysia. Journal of Current Southeast Asian Affairs 32(2):61-88.

Hansegård, Nils Erik (1968). Tvåspråkighet eller halvspråkighet. Stockholm: Aldus/Bonniers.

Hashim, Azirah (2009). Not plain sailing: Malaysia's language choice in policy and education. AILA Review 22(1):36-51.

Hymes, Dell. (1972). Models of the interaction of language and social life. In J Gumperz \& D Hymes (eds.), Directions in sociolinguistics: The ethnography of communication 35-71. New York: Holt, Rinehart, \& Winston.

Hymes, Dell. (1974). Foundations in sociolinguistics: An ethnographic approach. Philadelphia: University of Pennsylvania Press.

Hymes, Dell H (1980). Language in education: Ethnolinguistic essays. Washington D.C.: Center for Aplied Linguistics.

Applied LinguisticsJenkins, Jennifer, Cogo, Alessia \& Dewey, Martin (2011). Review of developments in research into English as a lingua franca. Language Teaching 44(3):281-315.

Jørgensen, Jens Normann (2008). Polylingual languaging around and among children and adolescents. International Journal of Multilingualism 5(3):161-176.

Lau, Yih-Long \& Ting, Su-Hie (2013). Chinese vendors' code-switching in service encounters in Sarawak, Malaysia. Sociolinguistic Studies 7(3):199-223.

Long, Michael (1987). Instructed interlanguage development. University of Hawai'i Working Papers in English as a Second Language 6(2):2-47. 
This is an Accepted Manuscript of an article published by Cambridge University Press,

Language in Society, available at https://www.cambridge.org/core/journals/language-in-

society/article/mother-tongues-and-languaging-in-malaysia-critical-linguistics-under-criticalexamination/63E9315695008B98517AA546BF6C5F54

Makoni, Sinfree \& Pennycook, Alastair (2005). Disinventing and (re)constituting languages. Critical Inquiry in Language Studies 2(3):137-156.

Makoni, Sinfree \& Pennycook, Alastair (2012). From monological multilingualism to multilingua francas. In Marilyn Martin-Jones, Adrian Blackledge \& Angela Creese (eds.), The Routledge Handbook of Multilingualism 439. Abington: Routledge.

Malay Mail Online (2015). Racial unity possible if race-based education abolished, Ahmad Zahid says. Kuala Lumpur.

McLellan, James (2012). Code-switching and the influence of "substrate" languages in the development of Southeast Asian Englishes. In E. L. Low \& Azirah Hashim (eds.), English in Southeast Asia: Features, policy and language in use 267-288. Amsterdam/Philadelphia: John Benjamins Publishing Company.

Milroy, Lesley \& Muysken, Pieter (eds.) (1995). One speaker, two languages: Cross-disciplinary perspectives on code-switching. Cambridge: Cambridge University Press.

Møller, Janus Spindler \& Jørgensen, Jens Normann (2009). From language to languaging: Changing relations between humans and linguistic features. Acta Linguistica Hafniensia 41(1):143-166.

Nil, Zurina Mohamed \& Paramasivam, Shamala (2012). Code-Switching in Gol \& Gincu. Procedia Social and Behavioral Sciences 66(169-175.

Noor, Noraini M \& Leong, Chan-Hoong (2013). Multiculturalism in Malaysia and Singapore: Contesting models. International Journal of Intercultural Relations 37(6):714-726.

Omar, Asmah Haji, Jaafar, Salinah \& Mat, Siti Ruhaizah Che (2015). Contact of dialect clusters: The Malay peninsula and Sumatera. Open Journal of Modern Linguistics 5(459-469.

Otsuji, Emi \& Pennycook, Alastair (2010). Metrolingualism: fixity, fluidity and language in flux. International Journal of Multilingualism 7(3):240-254.

Pennycook, Alastair (2002). Mother tongues, governmentality, and protectionism. International Journal of the Sociology of Language 2002(154):11-28.

Pennycook, Alastair (2004). Critical applied linguistics. In A. Davies \& C. Elder (eds.), The handbook of applied linguistics 784-807. Malden, MA: Blackwell.

Pennycook, Alastair (2014). Principled polycentrism and resourceful speakers. Journal of Asia TEFL 11(4):1-19.

Preston, Dennis (1994). Content-oriented discourse analysis and folk linguistics. Language Sciences 16(2):285-331.

Preston, Dennis (2005). What is folk linguistics? Why should you care? Lingua Posnaniensis: Czasopismo Poświecone Językoznawstwu Porównawczemu i Ogólnemu 47(143-162.

Preston, Dennis (1996). Whaddayaknow?: The modes of folk linguistic awareness. Language Awareness 5(1):40-74. 
This is an Accepted Manuscript of an article published by Cambridge University Press,

Language in Society, available at https://www.cambridge.org/core/journals/language-in-

society/article/mother-tongues-and-languaging-in-malaysia-critical-linguistics-under-criticalexamination/63E9315695008B98517AA546BF6C5F54

Preston, Dennis (2011). Methods in (applied) folk linguistics: Getting into the minds of the folk. AILA Review 24(1):15-39.

Ramsey, S Robert (1987). The languages of China. Princeton: Princeton University Press.

Ridge, Brian (2004). Bangsa Malaysia and recent Malaysian English language policies. Current Issues in Language Planning 5(4):407-423.

Ryon, Dominique (2005). Language death studies and local knowledge: The case of Cajun French. In A Suresh Canagarajah (ed.), Reclaiming the local in language policy and practice 55-72. Mawah: Lawrence Erlbaum.

Saraceni, Mario (2013). The language of Malaysian and Indonesian users of social networks: practice vs. system. In Rani Rubdy \& Lubna Alsagoff (eds.), The global-local interface and hybridity: Exploring language and identity 191-204. Bristol: Multilingual Matters.

Schiffman, Harold (1995a). Language shift in the Tamil communities of Malaysia and Singapore. Southwest Journal of Linguistics 14:151-165.

Schiffman, Harold (1995b). Linguistic culture and language policy. (The Politics of Language, New York: Routledge.

Schiffman, Harold (2006). Language policy and linguistic culture. In T Ricento (ed.), An introduction to language policy: Theory and method 111-125. Malden: Blackwell.

Shafie, Latisha Asmaak; Nayan, Surina (2013). Languages, code-switching practice and primary functions of Facebook among university students. Studies in English Language Teaching 1(1):187-199.

Silverstein, Michael (1996). Encountering language and languages of encounter in North American ethnohistory. Journal of Linguistic Anthropology 6(2):126-144.

Spolsky, Bernard (2004). Language Policy. Cambridge: Cambridge University Press.

Stark, Jan (2004). Constructing an Islamic model in two Malaysian states: PAS rule in Kelantan and Terengganu. Sojourn: Journal of Social Issues in Southeast Asia 19(1):51-75.

Stroud, Christopher (2003). Postmodernist perspectives on local languages: African mother-tongue education in times of globalisation. International Journal of Bilingual Education and Bilingualism 6(1):17-36.

Teo, Peter (2005). Mandarinising Singapore: A critical analysis of slogans in Singapore's 'Speak Mandarin' campaign. Critical Discourse Studies 2(2):121-142.

Wee, Lionel (2014). Linguistic chutzpah and the Speak Good Singlish movement. World Englishes 33 (1):85-99.

Wei, Li (2011). Moment Analysis and translanguaging space: Discursive construction of identities by multilingual Chinese youth in Britain. Journal of Pragmatics 43(5):1222-1235. 
This is an Accepted Manuscript of an article published by Cambridge University Press,

Language in Society, available at https://www.cambridge.org/core/journals/language-in-

society/article/mother-tongues-and-languaging-in-malaysia-critical-linguistics-under-criticalexamination/63E9315695008B98517AA546BF6C5F54

Widdowson, Henry (2001). Coming to terms with reality: Applied linguistics in perspective. Applied Linguistics for the 21st Century, AILA Review 14(2-17.

Wright, Sue (2003). Language policy and language planning: From nationalism to globalisation. Basingstoke: Palgrave Macmillan. 